6. Тертишник В.М. Науково-практичний коментар Кримінального процесуального кодексу України. Київ : Алерта, 2014. 768 с.

7. Кримінальний процес: підручник / за заг. ред. В.В. Коваленка, Л.Д. Удалової, Д.П. Письменного та інші. Київ : «Центр учбової літератури» 2013. 544 с.

8. Кримінальний процесуальний кодекс України: наук.-практ. коментар / С.В. Ківалов, С.М. Міщенко, В.Ю. Захарченко. Харків : Одіссей, 2013. 1104 с.

9. Овчаров Д. Тариф на свободу корупціонерів, або Чи варто випускати під заставу. Юридичний вісник України. 2015. № 11. С. 7.

10. Кучинська О.П. Принципи кримінального провадження в механізмі забезпечення прав його учасників : монографія. Київ : Юрінком Інтер, 2013. 288 с.

11. Макаров М.А. Судовий контроль у кримінальному провадженні: монографія. Київ, KHT, 2016. $403 \mathrm{c}$.

12. Про оперативно-розшукову діяльність: Закон від 18 лют. 1992 р. № 2135-ХІІ. Верховна Рада Украӥни. URL: zakon.rada.gov.ua/go/2135-12.

13. Ганжа О.О. Проблемні аспекти протидії оперативними підрозділами ОВС України діяльності організованих груп, які готують учинення крадіжок із квартир громадян. Вісник Харківського національного університету внутрішніх справ. 2013. URL: http://visnyk.univd.edu.ua.

14. Сергєєва Д.Б. Результати негласних слідчих (розшукових) дій: проблемні аспекти визначення. Право і громадянське суспільство. 2014. № 1 (6). С. 97-106.

15. Колесник В.А. Негласні слідчі (розшукові) дії: кримінально-процесуальні та криміналістичні аспекти підготовки і проведення : наук.-практ. посіб. Київ : Прецендент, 2014. 135 с.

УДК 343.1

DOI https://doi.org/10.32844/2618-1258.2019.3-2.27

КОЗАЧЕНКО О.І., ШАРАНИЧ Р.С.

\title{
ОСОБЛИВОСТІ ПОЧАТКОВОГО ЕТАПУ РОЗСЛІДУВАННЯ КРИМІНАЛЬНИХ ПРОВАДЖЕНЬ ПРО ЗЛОЧИНИ У СФЕРІ БАНКІВСЬКОГО КРЕДИТУВАННЯ
}

\begin{abstract}
У статті розглянуто особливості початку досудового розслідування кримінальних проваджень про злочини у сфері банківського кредитування. На основі наукових підходів виокремлено специфіку оцінки слідчим початкової інформації про злочин на основі перевірки одержаних заяв і повідомлень громадян (клієнтів банків), яким завдано шкоду, повідомлень службових осіб банків за результатами «внутрішніх» розслідувань, актів державних контролюючих органів, матеріалів уповноважених службових осіб, які затримали особу під час учинення злочину, а також у разі безпосереднього виявлення ознак злочину за матеріалами оперативних підрозділів.

Визначено, що виявлення злочинів розглядається, по-перше, як одержання органом досудового розслідування з різних джерел інформації про ознаки кримінального правопорушення; по-друге, як результат цієї діяльності, що є підставою для початку досудового розслідування; по-третє, як встановлення обставин учинення інших злочинів під час досудового розслідування.

Зроблено висновок, що початковий етап розслідування використовується для позначення певного періоду досудового розслідування, під час якого слідчий
\end{abstract}

( С КОЗАЧЕНКО О.І. - кандидат юридичних наук, старший науковий співробітник, професор кафедри управління безпекою, правоохоронної та антикорупційної діяльності (Інститут права імені князя Володимира Великого Міжрегіональної академії управління персоналом)

(C) ШАРАНИЧ Р.С. - аспірант (Інститут права імені князя Володимира Великого Міжрегіональної академії управління персоналом) 
здійснює організаційні заходи для встановлення усіх обставин злочину та особи підозрюваного. Основна спрямованість початкового етапу розслідування - інтенсивний пошук, виявлення і закріплення доказів шляхом проведення слідчих (розшукових) дій, негласних слідчих (розшукових) дій та оперативно-розшукових заходів. На цьому етапі здійснюється основна робота по розслідуванню кримінальних проваджень про злочини у сфері банківського кредитування, зокрема після внесення відомостей до ЄРДР до фактичного оголошення підозри особі на плановій основі слід провести такі дії: витребувати від органів державної влади, місцевого самоврядування, підприємств, установ та організацій, службових і фізичних осіб речі, документи, висновки експертів, акти ревізій і перевірок; звернутися в установленому порядку до слідчого судді з клопотанням про тимчасовий доступ до предметів і документів, зокрема які містять охоронювану законом таємницю (про рух коштів на банківських рахунках за певний період, копії документів, на підставі яких перераховувалися кошти) та, в разі прийняття відповідного рішення, вилучити їх; призначити ревізії та фінансові перевірки суб'єктів господарювання (банків); провести (доручити проведення) слідчі (розшукові) дії та негласні слідчі (розшукові) дії; призначити необхідні експертизи.

Ключові слова: банківське кредитування; початковий етап розслідування, досудове розслідування, слідчі (розщукові) діі.

The article deals with the peculiarities of the beginning of pre-trial investigation of criminal proceedings on bank lending crimes. On the basis of scientific approaches the specificity of evaluation by the investigators of initial information about a crime is distinguished on the basis of verification of received statements and messages of citizens (clients of banks) who have been harmed, reports of bank officials on the results of "internal" investigations, acts of state controlling bodies, materials of authorized officials, materials of authorized officials who detained a person during the commission of a crime, as well as in the case of direct detection of signs of a crime by the materials of the operational units.

It is determined that detection of crimes is considered, first of all, as the receipt by the body of pre-trial investigation from various sources of information about the signs of a criminal offense; second, as a result of this activity, which is the basis for the initiation of the pre-trial investigation; third, as establishing the circumstances of the commission of other crimes during the pre-trial investigation. It is concluded that the initial stage of the investigation is used to indicate a certain period of pre-trial investigation, during which the investigator takes organizational measures to establish all the circumstances of the crime and the identity of the suspect.

The primary focus of the initial phase of the investigation is the intensive search, detection and consolidation of evidence by conducting investigative (search) actions, unspoken investigative (search) actions, and operational-search measures. At this stage, major work is underway to investigate criminal proceedings for bank lending crimes, in particular, after the ERDF has been entered into the actual announcement of suspicion on a planned basis, the following actions should be carried out: demand from state authorities, local self-government, enterprises, institutions and organizations, officials and individuals things, documents, expert opinions, acts of audits and inspections; to apply in due course to the investigating judge with a request for temporary access to subjects and documents, in particular, which contain the secrecy of the law (about the movement of funds in bank accounts for a certain period, copies of documents on the basis of which the funds were transferred) and, if the appropriate decision is made, remove them; appoint audits and financial audits of business entities (banks); to conduct (instruct) conducting investigative (search) actions and unspoken investigative (search) actions; appoint the necessary expertise.

Key words: bank lending; initial stage of investigation, pre-trial investigation, investigative (investigative) actions. 
Вступ. Сучасна кредитно-банківська сфера переживає серйозні структурні зміни в умовах переходу від адміністративно-керованої високомонополізованої державної банківської структури до динамічної, гнучкої, заснованої на приватній та колективній власності системи кредитних установ. Істотні зміни відбуваються також у діяльності банків. Сьогодні вони практично набули свого комерційного вигляду. 3 установ, зайнятих головним чином розподілом короткострокових та довгострокових кредитів між господарськими організаціями, банки перетворюються в ринкові структури, орієнтовані на комерційний успіх, на одержання прибутку. Банківська сфера, яка складає стратегічний сегмент ринкової економіки, відіграє провідну роль у здійсненні економічних відносин. Вивчення статистичних даних показує, що злочинність у цій галузі перетворилась у масштабне явище саме за роки економічних реформ. Кримінальні посягання тут відрізняються різноманітністю, високоінтелектуальним характером, швидкою адаптацією злочинців до нових форм та методів підприємницької діяльності, нових технологій здійснення банківських операцій.

Результати дослідження. Розслідування злочинів є пізнавальною діяльністю, яка має на меті отримати вірогідні відомості про об'єкт, який представляє цікавість для слідства, і як будьяка діяльність має певну структуру. В.В. Рябоконь та В.І. Шиконов запропонували два основні елементи процесу розслідування злочинів: етапи розслідування та окремі слідчі дії на цих етапах $[1$, c. 5]. Автори підтримують таку думку вчених і будуть вирішувати поставлені завдання за таким напрямом.

Питання початкового етапу розслідування злочину в криміналістиці вивчають уже багато років. У криміналістичній літературі зверталась увага на практичне значення дослідження та розробки початкового етапу в методиці розслідування злочину. Різноманітні аспекти даного структурного елементу процесу розслідування неодноразово розглядалися в роботах Р.С. Бєлкіна, B.I. Галагана, С.П. Іщенка, I.M. Лузгіна, В.І. Лунгу, А.Г. Філіппова та інших. Водночас існують неоднозначні думки з цього питання, які потребують подальшого дослідження.

Враховуючи пізнавальний характер розслідування, І.М. Лузгін виділяє два етапи розслідування. Перший - починаючи від порушення кримінальної справи до пред'явлення обвинувачення. На цьому етапі збираються та оцінюються фактичні дані, необхідні для вирішення питання про порушення кримінальної справи, затримання обвинуваченого та пред'явлення обвинувачення. Другий етап - від пред'явлення обвинувачення до закінчення слідства. Головна мета даного етапу - дослідження та оцінка доказів із урахуванням показань обвинуваченого та прийняття рішення у справі [2, с. 89].

P.С. Бєлкін спочатку також поділив процес розслідування на два етапи - початковий та наступний, визначивши для них конкретні завдання. Серед них важливе завдання початкового етапу розслідування вбачав у орієнтуванні особи, яка провадить досудове слідство, в обставинах події й отриманні вихідних даних для планування розслідування, з'ясування фактів, які підлягають доказуванню в справі. Також вказав на необхідності збору і фіксації доказів, які можуть бути втрачені, та в установленні, розшуку та затриманні злочинця за «гарячими слідами». Починаючи з 70-х років, у криміналістичних працях переважає думка про поділ процесу розслідування на три етапи. Р.С. Бєлкін доходить висновку, що процес розслідування злочину доцільно поділити на три взаємопов'язані етапи: початковий або етап початкових слідчих дій та оперативно-розшукових заходів; наступний, або етап наступних слідчих дій та оперативно-розшукових заходів та заключний етап [3, с. 33-34].

На думку М.П. Яблокова, розслідування злочинів проходить у своєму розвитку три етапи: початковий, наступний та заключний. На початковому етапі висувають версії, складають план розслідування та проводять початкові слідчі дії. На наступному етапі основним напрямком розслідування $є$ встановлення злочинця та його розшук, а при затриманні - збір додаткових фактичних даних, які б його викрили, пред'явлення йому обвинувачення. На заключному етапі здійснюється підготовка й виконання вимог, пов'язаних із закінченням розслідування [4, с. 495-497].

В.К. Лисиченко пропонує розділити розслідування на два взаємопов’язані етапи - початковий та наступний. На початковому етапі розслідування після порушення кримінальної справи основною задачею розслідування $є$ вивчення обставин події, виявлення та фіксація слідів та інших доказів, особливо тих, що швидко змінюються чи взагалі можуть зникнути. Наступний етап розслідування починається після пред’явлення підозрюваному постанови про притягнення як обвинуваченого та його допиту [5, с. 100-114].

Криміналістичний поділ процесу розслідування на взаємозалежні етапи має завдання щодо встановлення структури криміналістичної методики розслідування злочинів, яка б включала в себе комплекс криміналістичних рекомендацій, тактику проведення слідчих дій і оперативно- 
розшукових заходів для розслідування й попередження злочинів. Це необхідно для усвідомлення чіткої сутності кожного етапу розслідування та оптимізації діяльності розслідування злочинів.

Початковий етап розслідування кримінальних проваджень про злочини у сфері банківського кредитування - суто криміналістичне, використовується для позначення певного періоду досудового розслідування, під час якого слідчий провадить слідчі (розшукові) дії, негласні слідчі (розшукові) дії та організаційні заходи для встановлення усіх обставин кримінального правопорушення та особи підозрюваного.

Серед проблем організації розслідування злочинів цієї категорії слід виокремити недостатній рівень обізнаності працівників територіальних підрозділів Національної поліції України 3 особливостями схем учинення злочинів з властивими їм ознаками, а також банківських операцій та інформаційно-телекомунікаційних технологій (85,5\% опитаних), що потребує напрацювання відповідних методик документування і викриття злочинів, проведення спільних семінарів і тренінгів для працівників практичних підрозділів Національної поліції України за участю фахівців банківської сфери, спеціалістів у галузі комп'ютерних технологій [6, с. 19].

Кримінальне провадження щодо злочинів у сфері банківського кредитування розпочинається 3 моменту внесення відомостей до Єдиного реєстру досудових розслідувань. Відомо, що успішне розслідування будь-якого злочину, у тому числі й злочинів у сфері банківського кредитування, безпосередньо залежить від того, як швидко після вчинення суспільно небезпечного діяння розпочато досудове розслідування. У зв'язку з цим особливої актуальності і значущості, на наш погляд, набуває етап збору та перевірки матеріалів. Особливість даного етапу багато в чому визначається кримінально-правовою природою розглянутих злочинів і тим, що дії, що становлять цю стадію, спрямовані на встановлення особи, яка ймовірно вчинила це правопорушення.

Відповідно до Інструкції про порядок ведення єдиного обліку в органах поліції заяв і повідомлень про вчинені кримінальні правопорушення та інші події, затвердженої наказом МВС України від 06.11.2015 № 1377 (далі - Інструкція), уповноважений працівник чергової частини органу поліції, отримавши заяву (повідомлення) про вчинене кримінальне правопорушення та іншу подію, відразу реєструє iï (його) в журналі Єдиного обліку та направляє на місце події слідчо-оперативну групу чи групу реагування (п. 2 розділу 2) [7]. Керівник органу досудового розслідування визначає слідчого, який реєструє заяву в Єдиному реєстрі досудових розслідувань та починає провадження (ч. 2 ст. 39 КПК України) [8].

На початку кримінального провадження щодо злочинів у сфері банківського кредитування до СРДР вносяться відомості про:

1) дату надходження заяви, повідомлення про злочини у сфері банківського кредитування або виявлення з іншого джерела обставин, що можуть свідчити про вчинення такого злочину;

2) прізвище, ім'я, по батькові потерпілого або заявника;

3) інше джерело, з якого виявлені обставини, що можуть свідчити про вчинення злочинів у сфері банківського кредитування;

4) короткий виклад обставин, що можуть свідчити про вчинення злочинів у сфері банківського кредитування, наведених потерпілим, заявником чи виявлених з іншого джерела;

5) попередня правова кваліфікація кримінального правопорушення із зазначенням статті (частини статті) закону України про кримінальну відповідальність;

6) прізвище, ім'я, по батькові та посада слідчого, прокурора, який вніс відомості до реєстру та розпочав розслідування;

7) інші обставини, передбачені положенням про Єдиний реєстр досудових розслідувань [9].

Як свідчить слідча практика, після внесення відомостей до ЄРДР та початку досудового розслідування про незаконне одержання кредиту залежно від способу злочину підлягають встановленню:

- обставини, за яких було створено підприємство-позичальник, наскільки законні його створення, діяльність стосовно конкретної організаційно-правової форми;

- наявність слідів матеріальної або інтелектуальної підробки документів, наданих до банку з метою одержання кредиту; технологічні особливості процесу кредитування, відповідність процедури кредитування вимогам чинних норматив-но-правових актів;

- напрями використання кредитних коштів, цільовий характер використання, можливі факти розкрадання кредитних коштів, фактичне місцезнаходження кредитних коштів, загальна сума заподіяної шкоди;

- учасники незаконного одержання кредиту (злочинна група), роль та місце кожного у злочинній діяльності [6, с. 81]. 
Вивчення кримінальних проваджень даної категорії показало, що приводами для внесення відомостей до ЄРДР є: заяви і повідомлення громадян (клієнтів банків), яким завдано шкоду (29\% кримінальних проваджень); повідомлень службових осіб банків за результатами «внутрішніх» розслідувань (38\%); акти державних контролюючих органів (7\%); матеріали уповноважених службових осіб, які затримали особу під час учинення злочину $(6 \%)$; безпосереднє виявлення ознак злочину за матеріалами оперативних підрозділів (10\%) або інших кримінальних проваджень (10\%). Незалежно від джерел виявлення початкової інформації про злочин, до матеріалів кримінального провадження долучаються: заява фізичної особи (лист-повідомлення представника банку) про кримінальне правопорушення; рапорт співробітника оперативного підрозділу 3 узагальненням результатів роботи щодо виявлення та документування злочину; пояснення потерпілого (його представника), свідків, затриманого; документи (іх копії), що підтверджують рух коштів на банківських рахунках; протокол огляду місця події з додатками.

Початковий етап розслідування таких кримінальних проваджень використовується для позначення певного періоду досудового розслідування, під час якого слідчий здійснює організаційні заходи для встановлення усіх обставин злочину та особи підозрюваного. Основна спрямованість початкового етапу розслідування - інтенсивний пошук, виявлення і закріплення доказів шляхом проведення СРД, НСРД та оперативно-розшукових заходів. На цьому етапі здійснюється основна робота по розслідуванню.

На початковому етапі розслідування кримінальних проваджень про злочини у сфері банківського кредитування слідчий у своєму розпорядженні повинен мати такі матеріали: а) рапорт про виявлення кримінального правопорушення; б) зареєстроване повідомлення про початок досудового розслідування; в) доручення про проведення досудового розслідування; г) детальні відомості про те, при яких обставинах було вчинено кримінальне правопорушення; д) протокол огляду місця події; ж) протокол за результатами «внутрішніх» розслідувань банку; з) акт державного контролюючого органу; е) протокол затримання уповноважених службових осіб, які затримали особу під час учинення злочину.

Не поодинокими $є$ випадки виявлення злочинів у сфері банківського кредитування за допомогою проведення оперативно-розшукової діяльності. Так, у статті 6 Закону України «Про оперативно-розшукову діяльність» [10] передбачено виключні підстави для її проведення. Такими підставами вважається наявності достатньої інформації, одержаної в установленому законом порядку, що потребує перевірки за допомогою оперативно-розшукових заходів і засобів, про:

- злочин, що готується;

- осіб, які готують вчинення злочину.

Основне джерело поінформованості компетентних органів пов'язане із сферою діяльності оперативно-розшукових органів. Це пояснюється завуальованістю, глибоким та всебічним маскуванням злочину, використанням легальних форм діяльності, з одного боку, та нерідко незацікавленістю несумлінних учасників економічної діяльності, зокрема банківських структур у виявленні злочинів, з іншого [6, с. 73-74].

Особливість одержання вихідних даних про злочини у сфері банківського кредитування шляхом проведення оперативно-розшукових заходів полягає у використанні різноманітних каналів надходження інформації про злочин та у подоланні протидії цієї діяльності з боку зацікавлених осіб, що зумовлює складні ситуації перевірки. На основі опитування оперативних працівників Департаменту захисту економіки Національної поліції України встановлено, що каналами одержання первинної інформації про злочини у сфері банківського кредитування є:

- конфіденційні джерела, що перебувають на зв'язку в оперативного працівника;

- матеріали перевірок фінансово-господарської діяльності суб'єктів підприємницької діяльності та банків органами державного контролю та нагляду;

- матеріали планових перевірок правоохоронних органів;

- повідомлення банків або інших кредитних організацій;

- заяви та повідомлення громадян.

Одержана таким чином інформація містить дані про факти нецільового використання кредитних коштів; сліди інтелектуальної або матеріальної підробки документів; факти створення або використання фіктивної підприємницької структури; про факти порушення процедури кредитування однією із сторін кредитного договору; факти злісного ухилення від погашення кредиторської заборгованості; про факти порушення фінансової або бухгалтерської звітності підприємством-позичальником.

Оцінка первинної інформації передбачає застосування комплексу знань, передусім економічних, криміналістичних, технічних. Перевірка інформації включає одночасну роботу 
за кількома напрямами: виявлення та одержання потрібних документів та їх копій; виявлення й «опрацювання» потрібних осіб; простежування руху грошей та інших цінностей, а також виявлення каналів їх неправомірного використання [6, с. 74]

Проведене авторами опитування оперативних працівників, які здійснюють обслуговування об'єктів банківського бізнесу показало, що опрацьованими практикою способами збирання даних, що вказують на вчинення злочинів досліджуваної категорії, є: організація проведення документальних ревізій, аудиторських перевірок, інше використання спеціальних економічних знань (71\% респондентів); тимчасовий доступ до речей та документів й одержання офіційних довідок (61\%); опитування громадян (58\%); витребування, дослідження та порівняльний аналіз документів (52\%); використання конфіденційних джерел інформації (44\%); перевірка фактичної наявності товарно-матеріальних цінностей та грошових коштів (36\%); спостереження за особою, річчю або місцем (33\%); прослуховування телефонних переговорів та зняття інформації 3 каналів зв'язку (19\%); моніторинг банківських рахунків тощо (5\%).

У КПК передбачено можливість одержання інформації про кримінальне правопорушення не лише через надходження заяв чи повідомлень, а й шляхом безпосереднього виявлення слідчим, прокурором або іншою службовою особою з будь-якого джерела обставин, що можуть свідчити про його вчинення. При виявленні в процесі досудового розслідування іншого кримінального правопорушення слідчий, за можливості, зобов'язаний прийняти таку заяву чи повідомлення та докласти зусиль для іiі подальшої реєстрації або оформити і зареєструвати рапорт про виявлення кримінального правопорушення. У разі безпосереднього виявлення ознак злочину чи кримінального проступку оперативним працівником, він повинен скласти рапорт і подати його начальникові правоохоронного органу (особі, яка виконує його обов'язки), який доручає його реєстрацію [11, с. 163$]$.

Особливістю інформаційних ресурсів, розміщених у мережі Інтернет, є те, що вони являють собою відкриту інформацію (таку, що не має обмежень, публічно доступну для необмеженого кола осіб, які можуть її законно отримати внаслідок звичайного запиту) або іншу нетаємну інформацію, що має обмежене публічне розповсюдження чи доступ. 3 огляду на виявлення ознак злочинів, усе різноманіття інформації, розміщеної в мережі Інтернет, можна поділити на дві великі групи: інформація про зміни, що виникли внаслідок впливу події злочину на інформаційне середовище (так звані «віртуальні сліди злочину»); інформація, що має орієнтувальний (допоміжний) характер [12, с. 34-35].

Проведений аналіз матеріалів кримінальних проваджень засвідчив, що злочини у сфері банківського кредитування, виявляються за таких обставин: 1) під час взаємодії користувачів 3 комп'ютерною системою (при експлуатації програмного забезпечення, обміні інформацією, використанні даних, проведенні перевірок тощо); 2) унаслідок проведення регулярних перевірочних заходів співробітниками служб банківської безпеки або фахівцями із захисту інформації, що перебувають у штаті користувача або провайдера; 3) під час проведення документальних перевірок і ревізій; 4) у процесі здійснення оперативно-розшукових заходів, проведених правоохоронними органами; 5) випадково; 6) під час розслідування інших злочинів, зокрема у сфері інформаційно-телекомунікаційних технологій. Первинні дані про злочини можуть надходити і від окремих громадян, коли офіційні джерела (банківські установи) з різних міркувань не надають правоохоронним органам інформацію про підозру не сплати кредиту.

Висновки. Так, відправним моментом встановлення інформації про розслідування кримінальних проваджень про злочини у сфері банківського кредитування є етап застосування після внесення до Єдиного реєстру досудових розслідувань відомостей про кримінальне правопорушення процесуальних засобів щодо встановлення особи, яка ймовірно вчинила це правопорушення (строки цього етапу кримінальним процесуальним законом не встановлені).

Виявлення злочинів розглядається як одержання органом досудового розслідування з різних джерел інформації про ознаки кримінального правопорушення; як результат цієї діяльності, що є підставою для початку досудового розслідування; як встановлення обставин учинення інших злочинів під час досудового розслідування. Засобом виявлення злочинів поряд з оперативно-розшуковою та кримінальною процесуальною діяльністю, вважається також «внутрішнє» розслідування банку. Відтак, удосконалення виявлення злочинів пов'язано з правовим закріпленням принципів і форм участі в цій роботі уповноважених працівників банків шляхом прийняття Закону України «Про приватну детективну (розшукову) діяльність» 3 коригуванням положень законодавства 3 питань організації діяльності органів досудового розслідування та оперативних підрозділів. 
Початковий етап розслідування використовується для позначення певного періоду досудового розслідування, під час якого слідчий здійснює організаційні заходи для встановлення усіх обставин злочину та особи підозрюваного. Основна спрямованість початкового етапу розслідування - інтенсивний пошук, виявлення і закріплення доказів шляхом проведення слідчих (розшукових) дій, негласних слідчих (розшукових) дій та оперативно-розшукових заходів.

На цьому етапі здійснюється основна робота по розслідуванню кримінальних проваджень про злочини у сфері банківського кредитування, зокрема після внесення відомостей до ЄРДР до фактичного оголошення підозри особі на плановій основі слід провести такі дії: витребувати від органів державної влади, місцевого самоврядування, підприємств, установ та організацій, службових і фізичних осіб речі, документи, висновки експертів, акти ревізій і перевірок (відповідно до ч. 5 ст. 40, ч. 2 ст. 93 КПК України); звернутися в установленому порядку до слідчого судді 3 клопотанням про тимчасовий доступ до предметів і документів (ч. 1 ст. 160 КПК України), зокрема які містять охоронювану законом таємницю (про рух коштів на банківських рахунках за певний період, копії документів, на підставі яких перераховувалися кошти) та, в разі прийняття відповідного рішення, вилучити їх; призначити ревізії та фінансові перевірки суб'єктів господарювання (банків); провести (доручити проведення) слідчі (розшукові) дії та негласні слідчі (розшукові) дії; призначити необхідні експертизи.

\section{Список використаних джерел:}

1. Рябоконь В.В., Шиконов В.И. Организация и тактика повторных следственных действий: пособие. Иркутск : Издательство Иркутского университета, 1985. 96 с.

2. Лузгин И.М. Методологические проблемы расследования: пособие. М. : Юридическая литература, 1973. $127 \mathrm{c}$ $2001.837 \mathrm{c}$.

3. Белкин Р.С. Курс криминалистики: учеб. пособие. М. : ЮНИТИ-ДАНА, Закон и право,

4. Криминалистика : учебник / отв. ред. Н.П. Яблоков. М. : Юристъ, 1999. 718 с.

5. Советская криминалистика. Методика расследования отдельных видов преступлений / В.К. Лисиченко, В.И. Гончаренко, М.В. Салтевский и др.; под ред. В.К. Лисиченко. Киев : Вища школа. Головное изд-во, 1988. 405 с.

6. Чернявський С.С. Злочини у сфері банківського кредитування (проблеми розслідування та попередження) : навч. посіб. / за заг.ред. О.М. Джужи. Київ : Юрінком Інтер, 2003. 264 с.

7. Про затвердження Інструкції про порядок ведення єдиного обліку в органах поліції заяв і повідомлень про вчинені кримінальні правопорушення та інші події та положень про комісії: наказ МВС України від 06 листоп. 2015 р. № 1377. Верховна Рада України. URL: http://zakon4. rada.gov.ua/laws/show/z2095-12.

8. Кримінальний процесуальний кодекс України: Закон України від 13.04.2012 p. Верховна Рада України. URL: http://zakon3.rada.gov.ua/laws/show/4651-17.

9. Положення про порядок ведення Єдиного реєстру досудових розслідувань: наказ Генеральної прокуратури України від 6 квіт. 2016 р. № 139. Верховна Рада Украӥни. URL: https://zakon. rada.gov.ua/go/z0680-16.

10. Про оперативно-розшукову діяльність: Закон України від 18.02.1992 р. № 2135-XII. Верховна Рада України. URL: zakon.rada.gov.ua/go/2135-12.

11. Фінагеєв В. О. Початковий етап розслідування злочинів, пов'язаних з використанням засобів доступу до банківських рахунків. Юридичний часопис Національної академії внутрішніх справ. 2012. № 2. С. 130-138.

12. Мещеряков В.А. Преступления в сфере компьютерной информации: основы теории и практики расследования. Воронеж : Изд-во Воронеж. гос. ун-та, 2002. 407 с. 